\title{
Organizational Performance: The Role of TQM Practices in Banking Sector of Pakistan
}

\author{
Nida Nazar (PhD Scholar) \\ Dr. Sara Ravan Ramzani (Senior lecturer) \\ Temoor Anjum (PhD Scholar) \\ Imran Ahmed Shahzad (PhD Scholar) \\ Post Graduate Centre-PGC, Limkokwing University of Creative Technology \\ Cyberjaya, Selangor, Malaysia
}

Doi:10.19044/esj.2018.v14n31p278 URL:http://dx.doi.org/10.19044/esj.2018.v14n31p278

\begin{abstract}
The main purpose of this study was to investigate the $\mathrm{m}$ relationship between Total Quality Management (TQM) and Organizational Performance (OP). The motivation for this study was driven by the inconsistent findings in the literature concerning the relationships between TQM and OP. Due to the inconsistent results, a new research has emerged and this has prompted further investigation on the effects of other variables that may better explain the nature of these links. Questionnaires were distributed to 400 Sections of the Pakistani banks. 230 questionnaires were returned and used in the analysis using the PLS-SEM. The results of this study revealed that TQM is significant predictors of OP.
\end{abstract}

Keywords: Total Quality Management, Organizational Performance Banking Sector, Pakistan, SEM PLS

\section{Introduction}

In the past decades, Organizational performance has been theoretically proven to be the concern of both practitioners and academics, as the end result of implementing tangible and intangible resources. Intangible resources are usually of more value than tangible resources in terms of effectiveness and the success of organizations. Management literature extensively investigated organizational performance construct in order to identify the clincher of high organizational performance. Simply put, empirical literature has an array of research that checks the effect of some strategies on organizational performance. One of such strategies is Total Quality Management (TQM). TQM is a management philosophy related to the overall organizational quality 
through continuous improvement in order to achieve a high level of customer satisfaction. It is widely accepted as the major determining factor of an advanced organizational performance and competitive advantage (Douglas \& Judge Jr, 2001; Dubey, 2015). Although the effect of TQM on organizational performance has been ascertained by many studies (Dubey, Singh, \& Ali, 2015; Sahoo \& Yadav, 2017; Thai \& Jie, 2018) some studies (Kober, Subraamanniam, \& Watson, 2012; Samson \& Terziovski, 1999) have argued that TQM has failed in some of its initiatives. Hence, there have been calls for further research to be carried out in order to ascertain and bridge the theoretical gap.

Total Quality Management has experienced wide recognition from the different sectors of the economy such as healthcare (Kaplan et al., 2010), manufacturing (Fotopoulos and Psomas, 2009), service (Feng et al., 2008), banking (Irfan et al., 2009), government (Chen, 2005), and education (Faganel, 2010; Manivannan and Premila, 2011). Ascertaining the reach of TQM, Noronha (2002) concluded that - although a few might argue - since Frederick Taylor's Scientific Management at the beginning of the century, no other management strategy has been able to accomplish what TQM has achieved (Ross, 1993). Further studies have gone as far as stating that TQM brought about a second industrial revolution (Kanji, 1990; cited in Noronha, 2002). Prominent journals such as the International Journal of Management Reviews (Molina-Azorín et al., 2009), Academy of Management Review (Benner and Tushman, 2003), Journal of Operations Management ( $\mathrm{Zu}$ et al., 2008), Management Decision (Ehigie and McAndrew, 2005), and Total Quality Management (Hoang et al., 2010; Lam et al., 2008) has continued to publish TQM linked papers despite assertions that TQM is simply a managerial mirage. The continuous publications show that the assertions are not fully justified. Developed countries the likes of USA, Japan, UK and other European countries have been reaping the benefits embedded in TQM for decades, however, in the last decade, the demand for quality is no longer secluded to them as developing countries started penetrating the international market.

Developing countries are breaking trade barriers, opening their markets to international counterparts and experiencing striking growth in quality; which has led researchers to start scrutinizing the quality practices in developing countries (Satish and Srinivasan, 2010; Temtime, 2003; Al-Swidi and Mahmood, 2012; Hoang et al., 2006; Das et al., 2008; Khanna et al., 2010). With Pakistan as a case, studies have shown a positive relationship exists between TQM practices and firm performance in manufacturing (Awan and Bhatti, 2003; Awan et al., 2009; Malik et al., 2010; Raja et al., 2011; Saleem et al., 2011), and service sector (Vakani et al., 2009; Khan, 2010; Quraishi et al., 2010; Khurram and Jafri, 2011; Sajjad and Amjad, 2011; Richard Jimoh, 
Luqman Oyewobi, Rasheed I. \& Ibrahim W., 2018); however, these researches do not measure up to par, as researchers admit a limitation in statistical representation with a relatively small $\&$ an unfair sample size. It is therefore arguable that these studies are a suitable point of reference for Pakistan. Hence, this paper aims to empirically examine the relationship between TQM practices and performance, with focus on the banking sector.

\section{Organizational Performance}

In organizational studies, great effort has been expended to investigate the organizational performance determinants (Simpson, Padmore, \& Newman, 2012). That is because of the importance of the subject in reflecting the path of development for any organization, and because of the implications of these studies on organizational effectiveness and competitiveness (Sulaiman, Yusoff, \& Chelliah, 2010). Quality and quantity as it was previously known globally are different from that of the constantly changing world of today's consumers. There is a constant need for organizations to update their quality and quantity of service to meet today's customers need as they have become very critical of products and services. Today's customers have been aptly described through the "Picky-Fickle-Vocal-Vain" moniker. The best way to connect with them and gain customer loyalty is to be different; which has forced organizations to adopt innovative \& creative strategies and maintain a high-quality presence in order to stand out. Thus, many researchers in the organizational studies field find TQM practices as the centre focus of their study.

Management literature sees organizational performance as the most crucial constructs in strategic management area (Combs, Crook \& Shook, 2005), which explains why researchers have conducted different researchers over the years in that aspect trying to give an insight into the antecedents, processes and other factors that can contribute to the improvement of organizational outcomes (Jing \& Avery, 2008). Literature in this context gained a considerable portion from the importance of organizational performance exuding from top management who are often interested in longterm success and competitiveness (Finkelstein \& Hambrick, 1996). Organizations that provide their customers with services are primarily concerned with providing their customers with quality service that will satisfy their needs and desires (Al-Marri, et al., 2007, leaving researchers with no choice but to extend their studies and examine the rate of effective performance in the service sector and its clinchers.

\section{Bank Performance and the Overall Economic Development}

Schumpeter (1934), Gurley and Shaw (1955), Goldsmith (1969), and 
McKinnon (1973) have discovered a strong positive correlation between the level of development of the financial system and the rate of economic growth. In other words, effective financial system plays an important role in the economic development of the nation (Anderson \& Trap, 2003). This shows that adequate banking system facilitates business entities rising and management of funds which could cause the country's economic progress (Fase \& Abma, 2003). Developing new ideas and reviewing of policies by service-oriented firms, including banks, allow them to maintain the competitiveness and innovativeness of their performance. Many researches have been carried out in organizational performance literature to examine the cause and effects of organizational performance in both manufacturing and service organizations like banks. Financial institutions are the backbone of a country 's economy as they see to other sector's needs. Thus, researchers paid adequate attention while investigating the factors that could potentially impact on organizational performance and improve strategic competitiveness (AlMarri et al., 2007).

\section{Hypotheses Development}

Hypotheses were developed based on the findings of prior literature. In relation with the study's aims, the following sub-sections expatiates on how the this study's hypotheses were developed from previous literature.

\section{TQM Practices and Organizational Performance}

Reviews of literatures on to TQM reveal that researchers utilized different approaches in TQM conceptualization (Nair, 2006; Dhafer AlQahtani et., al. 2015). For instance, some studies such as Choi and Eboch (1998), Kaynak (2003), Das et al. (2000), and Terziovski (1999b) viewed the structure through its multiple dimensions, while other studies such as Arawati (2005), Arawati and Ridzuan (2001), (2001) made use of a single dimensional definition for the construct. Previous studies basked their view on the assumption of correlation between the factors of TQM, signifying that TQM strategy should be applied as a whole as opposed to individual practices. In relation to this, studies using Toral quality management as a single construct revealed a positive relationship between TQM strategy and organizational performance. Through the criteria laid down by TQM, several empirical studies (Choi \& Eboch, 1998 Flynn \& Saladin, 2001; Montes, Jover \& Fernandez, 2003; Samson \& Terziovski, 1999) have measured the performance of the organization.

A consequential part of TQM literature disclosed a positive TQM practices - organizational performance relationship (Sila \& Ebrahimpour, 2002). In addition to this, TQM practices where displayed as being capable of ensuring financial and nonfinancial actions en route their firm innovation 
path,(Singh \& Smith, 2004), boost organizational culture change (Irani, Bekese, \& Love, 2004), enhance competition in the market (Chong \& Rundus, 2004), improve growth of market share (Kaynak, 2003), increase productivity (Kaynak, 2003; Rahman \& Bullock, 2005), develop the confidence of employees (Rahman \& Bullock, 2005), and lastly, boost organizational performance in general (Powell, 1995). Previous researches and conclusions helped the researcher propound the following thesis;

\section{Hypothesis 1: TQM has a significant effect on organizational performance}

\section{TQM-Management Leadership and Organizational Performance}

Some authors - Terziovski \& Samson, 1999 among others - have argued that Total Quality Management can be viewed as a single construct when studying the relationship between TQM and organizational performance, while some authors - Powell, 1995; Dow et al., 1999 among others - are of the view that only some TQM practices positively relates with firm performance (Anuar, 2002; Montes \& Jover, 1004; Powell, 1995; Yasin et al., 2004). These mixed findings points to the fact that several TQM elements significantly affect the performance of the firm (Hendricks \& Singhal, 2001; Samson \& Terziovski, 1999). Emphasizing on well-known basis, Harrington and Williams (2004) states that the leadership component of TQM has been viewed as one of the top TQM strategy dimensions (Singh \& Sushil, 2012; Faisal, Rahman, \& Qureshi, 2011). That is, merely giving up control is not the most important role of leaders, but, the empowering of employees and providing them with adequate training, which enhances performance (Harrington \& Williams, 2004).

Additionally, the way leaders effectively and adequately use social and human capital in gaining competitive edge and the development of their organization shows a successful strategic leadership (Hitt \& Irel, 2002). According to Hitt and Ireland (2002), whether or not the level of strategic leadership in a firm has any role in its performance is a question of topmost importance in strategic leadership. In other words, management leadership is one of the top factors of TQM researchers focus on as the platform upon which they base any TQM initiative (Chuan \& Soon, 2000; Idress, 2011; Rula A,2017).

Developing a supportive organizational culture is an important role for top management, especially one with its basis on effective communication, teamwork, empowerment, participative decision making and effective training (Koehler \& Pankowski, 1996). Hence, TQM literature empirically recognizes the relationship between management leadership and organizational performance (Arawati, 2005; Flynn et al., 1995; Montes \& Jover, 2004; Powell, 1995; Valmohammafi, 2011 Yasin et al., 2004). Based on the above 
premise, the researcher proposes the following hypothesis;

Hypothesis 2: TQM-Management leadership significantly affects organizational performance.

\section{TQM-Customer Focus and Organizational Performance}

In quality management literature, the main aim of TQM strategy is to derive customer satisfaction and meet customer's expectations. It has seen to have failed if it does not add value to customers (Thiagarajan \& Zairi, 1997c). For success to be attained, continuous and effective communication between the firm and customers must be maintained while customers are given the opportunity to get involved in the design of products and services (Hunt, 1995). Customer involvement in marketing activities feeds on life-long relationship strategies through interactions. Additionally, customer-cantered databases listing customers' needs and expectations while keeping up-to-date with their satisfaction levels is a very important asset every organizations particularly banks should have.

Strategic positioning - the manner and the position where the organization competes from - is a significant TQM concepts that help organizations in maintaining a considerable level of customer satisfaction through their products and services that are of high quality and are innovative (Hooley, Fahy, Greenley \& Beracs, 2003). Several authors have previously and continually ascertained that customer satisfaction is crucial in the overall organizational performance and that the higher level of customer satisfaction, the lower the operating cost (Lee \& Hwan, 2005) which in turn, generates a greater profit (Matzler, Hinterhuber, Daxer, \& Huber, 2005) and the more improved will be the performance of the firm (Westland, Gustafsson, Lang, \& Mattsoon, 2005). Mehra et al. (2001) in their proposal for a TQM customercantered strategy, stresses the significance of customer-cantered view in the successful run of TQM initiatives; and according to the emphases provided by authors on both customer satisfaction and loyalty, it is evident that they are the fundamentals of every successful business. This view was confirmed by Mehra et al (2001) when they stated that the customer-centre element of TQM is going to be the most significant aspect of TQM literature.

In their quest to make profits and maximize market share, organizations need to maintain a loyal customer base by satisfying their customers 'expectations. This is why customer satisfaction has continued to gain scholars and practitioners 'focus as they have begun to acknowledge its importance in profit making. Agus et al. (2000) stated in a related study that the implementation of TQM strategy enhances the financial performance of the firm via customer-cantered activities. Studies such as Montes \& Jover, 2004; Yasin et al., 2004, provide evidence that ascertain customer focus is positively linked to firm performance. Based on the above discussion and evidences, the 
following hypothesis is proposed;

Hypothesis 3: TQM-Customer focus has a significant effect on organizational performance.

\section{TQM-Strategic Planning and Organizational Performance}

Strategic planning has to do with the activities through which the firm creates, applies and tests its strategies to achieve firm objectives (Srinidhi, 1998). It is priceless in combining TQM strategy with the rest of the firm strategies. That is, TQM strategic planning is interested in the capabilities of the firm - sufficient funds, experienced and skilled workers and enough time to meet planned goals (Black \& Porter, 1996).Expatiating the significance of strategic planning, some researchers state by that the ability of the organization to thrive in the constantly changing business environment is reflected through its policies on strategic planning (Chenhall, 2005). Additionally, top management is significantly involved in the TQM context through this TQM component (Krumwiede \& Charles, 2006) where the process the firm employs in transforming its vision and mission into plans and actions are considered (Tari, 2005). It is therefore pertinent for strategic planning, as a TQM strategy to draw a map that guides the manner in which the organization design its TQM practices in order to achieve its aims and to align them with the needs and expectations of customers (Sila \& Ebrahimpour, 2002). A thorough review of TQM literature shows previous studies revealed a significant strategic planning-organizational performance relationship - Li et al. (2003), Sila and Ebrahimpour (2005), Sila and Ebrahimpour (2002) and Wu et al. (1997) among others. Hence, the researcher proposes the following hypothesis for testing;

Hypothesis 4: TQM-Strategic Planning has a significant effect on organizational performance.

\section{TQM-Service Design and Organizational Performance}

Effective service design plays a key role in organizational performance as it enhances reputation and customer satisfaction (Lakhe \& Mohanty, 1995). Also, effective service design of a firm often results in advanced work processes, while reducing wasted time and increasing customer satisfaction and profitability. Additionally, the firm's financial performance can grow when the firm implements TQM as it maximizes efficiency and minimizes cost as stated by Arawati (2005) and Flynn et al. (1995). There also exist a significant relationship between service design and organizational performance as shown by other studies in this field - Anderson et al., 1994; Flynn et al., 1995; Montes \& Jover, 2004. Thus, this discussion led the researcher to propose the following hypothesis; 


\section{Hypothesis 5: TQM-Service design has a significant effect on organizational performance.}

\section{TQM-Information and Analysis System and Organizational Performance}

Total Quality management literature sees effective information system as one of the important factors that see to the success of the implementation of TQM initiatives (Ahire et al., 1996). The importance of an information system (combination of hardware, software, people and procedures) is the basis of majority of the national quality awards such as MBNQA to highlight its importance as one of the conditions of effectively managed organizations (Kartha, 2004). The relevance of such systems and analysis systems for effective firm performance, especially in this decade of connectivity with continuous upgrade of information and communication technology (ICT) was emphasized by Saraph et al. (1989). The studies claim that organizations with effective IS can readily react to the drastic and constant changes in the market because due to their capabilities (effective data collection, data presentation and data dissemination). With the same view, Flynn et al. (1995) displayed the presence of a positive association between quality information systems and organizational performance. They believe this is due to the thorough knowledge and effective use of customer-cantered information which can lead to considerable levels of customer satisfaction and efficient operations. Hence, the following hypothesis is proposed to be tested;

Hypothesis 6: TQM Information and Analysis System has a significant effect on organizational performance.

\section{TQM-Continuous Improvement and Organizational Performance}

Primarily, total quality management strategy has been referred to as a management philosophy that aims to achieve customer satisfaction through continuous efforts geared towards improvement at all levels (Benavent, Ros \& Moreno-Luzon, 2005). It is to need to continually improve all aspect in the organization and embarking on a never-ending search for improvement and to have better methods for improving all processes including inputs and outputs (Burli, Kotturshettar, \& Dalmia, 2012). Therefore, it is important for organizations to extend their ongoing improvement activities to cover such processes as management activities as well as management styles (Benavent et al., 2005).

Although there can be considerable deviation between the organizational vision and its operational situation, but this may be resolved through effective management system processes (Landau, Drori \& Porras, 2006). This is true considering the fact that the main aim of any organization is to generate results that achieve customer satisfaction while exceeding customers' expectations. This shows the importance of evaluating managerial 
and technical processes in organizations based on their contribution to achieving customer satisfaction (Baker, 2003). Or better stated, the present dynamic business market requires organizations to carefully consider their requirement to adopt life-long ongoing enhancement strategies involving the entire organizational members; and according to Dean and Bowen (1994), the need for ongoing improvement strategies was boosted by critical innovation and quality-seeking customers who will not settle for less. Several factors including top management support, effective HRM and efficient information systems that gathers and analyses information to ascertain practices that need enhancement, may support the assertion (Escrig-Tena, 2004) . Studies dedicated to quality management such as Anderson et al., 1994; Christos Fotopoulos \& Psomas, 2010; Flynn et al., 1995; Li et al., 2003; Montes \& over, 2004; Powell, 1995) showed ongoing improvement practices enable organizations to perform better. The following hypothesis is therefore proposed;

Hypothesis 7: TQM Continuous Improvement has a significant effect on organizational performance.

\section{TQM-Benchmarking and Organizational Performance}

As a continuous systematic approach, benchmarking is one of the important CSFs of TQM to measure the key business process against the best practice of the industry (Singh \& Sushil, 2012). Benchmarking strategy is useful for organizations to keep abreast of market performance by comparing themselves to their leading competitors. The essence behind such strategy is to examine the products, services and methods used by competitors in the same industry or other industries with the objective of gaining competitive edge (Ahire et al., 1996). Aspects of other organizations that may be benchmarked by an organization include cost savings, process efficiency, employee satisfaction and customer satisfaction. The positive impact of benchmarking on the performance of the firm has been evidenced by several researchers such as Ahire et al. (1996), Arawati (2005), Powell (1995),Christos et al,(2010); Sanchez-Rodriguez and Martinez-Lorente, (2004). On the basis of the above findings, the researcher proposes the following hypothesis;

Hypothesis8: TQM-Benchmarking has a significant effect on organizational performance

\section{Methods and Measures}

Organizational performance: Organizational performance measurement was obtained from studies in literature dedicated to management. Specifically, Narver and Slater's (1990) and Jaworksi and Kohli's (1993) measures were found widely used and easily adaptable in all cultural setting. Keepin in veiw the depth and the overall coverage of the dimensions of the 
exploerd items same measures were adopted for the measurement of the performance. Further to this inroder to have an holistic vew of the developed hypothese and phenomenon, some items were adopted from Chan (2004), Fuentes-Fuentes (2004), and Kaplan and Norton (1993).

TQM Measure: In the present study, the critical factors of TQM strategy are encapsulated through the use of relevant TQM factors that have been extensively utilized in the service sector. From this study's research framework, it is evident eight factors characterize TQM strategy and they are management, leadership, customer focus, strategic planning, human resource management, service design, information and analysis, continuous improvement and finally, benchmark.

\section{Data Collection}

One of the main aims of the present study was to test the hypothesized relationships on the business unit level and hence, the study's unit of analysis was bank branch represented by the branch manager. In this regard, Hepworth (1998) claimed that adding new management initiatives offers advantages to the organizational level as well as the management level. Majority of prior studies on TQM were carried out at the organizational level and thus, the present study contributes to literature concerning TQM strategies at the bank branch level. In the context of banking sector, examining the impact of TQM has become significant as the significance of their contribution to successful implementation of strategy is increasingly becoming important.

The next section discusses reasons behind why bank branch was chosen as unit of analysis in this study. First, bank branches occupy an important position in the banking sector (Athanassopoulos, 1997), as they directly relate customers with the banks and competitive advantage is created through their value creation processes. Second, bank branches are the liaisons between the bank and clients, and thus the bank's performance as a whole largely depends on the branches operations as stated 155 by Das, Ray and Nag (2009). They added that bank branches have a significant position in the bank's OP success as they mobilize the deposits and as a result, they also produce funds for the bank's investment processes. In other words, the bank branches performance may cause the success or collapse of the whole bank. As such, the performance and efficiency of the bank branches have been increasingly examined by researchers. Finally, several academicians have primarily focused on business units in their examination of TQM practices (Saraph et al., 1980), market orientation (Dwairi, Bhuian \& Jukus, 2007), and strategies of TQM (Reed, Lemak \& Montgomery, 1996). The importance of bank branches as a unit of study was also backed by many studies that examined TQM applicability and other innovative strategies at the bank branch level. Specifically, Longo and Cox (2000) distributed a questionnaire among 160 bank branch managers in 
the U.K. indicating that branches are considered as strategic business units wherein competitive advantage is developed via effective strategies. Other studies claimed that bank branches should be the core of strategic execution of the corporate bank and it is the best level upon which the level and outcomes of such strategy may be observed.

The appropriate survey administration considerably impacts the satisfactory responses of the data gathered. Hence, the present study made use of self-administered questionnaire as the primary tool for data collection. In this regard, the quantitative method of study is invaluable in transformation information using the questionnaire into significant outcomes that contributes to research development (Cooper \& Schindler, 2006). Such a method allowed the respondents to clarify ambiguities and the data collectors to confirm missing data from the respondents. Some bank branches were assisted by their headquarters in providing the much needed data.

\section{Data Analysis}

After data collection procedure, descriptive and inferential statistics were used for data analysis. In particular, the PLS-SEM method was employed to analyze the collected data. The Partial Least Squares technique is a powerful component-based method widely used in prior studies (Farrukh, Khan, et al., 2017; Farrukh, Chong, Mansori, \& Ravan Ramzani, 2017; Farrukh, Wei Ying, \& Abdallah Ahmed, 2016; Farrukh, Ying, \& Mansori, 2016, 2017; Riaz, Farrukh, Rehman, \& Ishaque, 2016; Shahzad, Farrukh, Kanwal, \& Sakib, 2018).

\section{Measurement Model}

Prior to hypotheses testing, the Partial Least Squares Structural Equation Modeling (PLS-SEM) was employed to assess the measurement model's outer model. The following phases, suggested by James C Anderson and Gerbing (1988) were followed. This process confirms construct validity. Construct validity can be assessed through the construct's content validity, convergent validity and discriminant validity. Table 1 shows the results of measurement model evaluation.

Table1: Measurement Model evaluation

\begin{tabular}{lllllll}
\hline Construct & Items & Loading & $\begin{array}{l}\text { Cronbach's } \\
\text { Alpha }\end{array}$ & CR & AVE \\
\hline Benchmarking & B1 & 0.887 & 0.904 & 0.933 & 0.777 \\
& B2 & 0.833 & & & \\
B3 & 0.901 & & & \\
Customer Focus & B4 & 0.903 & & 0.922 & 0.702 \\
& CF2 & 0.858 & 0.894 & & \\
& CF3 & 0.871 & & & \\
& CF4 & 0.79 & & & \\
& CF5 & 0.823 & & & \\
\end{tabular}




\begin{tabular}{|c|c|c|c|c|c|}
\hline & CF6 & 0.846 & & & \\
\hline \multirow[t]{4}{*}{ Continuous Improvement } & CI1 & 0.84 & 0.854 & 0.902 & 0.697 \\
\hline & $\mathrm{CI} 2$ & 0.899 & & & \\
\hline & $\mathrm{CI} 3$ & 0.819 & & & \\
\hline & CI4 & 0.777 & & & \\
\hline \multirow[t]{5}{*}{ Customer Orientation } & Cuo1 & 0.867 & 0.945 & 0.956 & 0.785 \\
\hline & Cuo2 & 0.854 & & & \\
\hline & Cuo3 & 0.907 & & & \\
\hline & Cuo4 & 0.894 & & & \\
\hline & Cuo5 & 0.873 & & & \\
\hline \multirow[t]{7}{*}{ Information and Analysis } & IA 1 & 0.804 & 0.909 & 0.928 & 0.648 \\
\hline & IA2 & 0.754 & & & \\
\hline & IA3 & 0.863 & & & \\
\hline & IA4 & 0.848 & & & \\
\hline & IA5 & 0.759 & & & \\
\hline & IA6 & 0.797 & & & \\
\hline & IA7 & 0.804 & & & \\
\hline \multirow[t]{5}{*}{ Management Leadership } & ML1 & 0.837 & 0.866 & 0.903 & 0.65 \\
\hline & ML2 & 0.811 & & & \\
\hline & ML3 & 0.801 & & & \\
\hline & ML4 & 0.769 & & & \\
\hline & ML5 & 0.812 & & & \\
\hline \multirow[t]{5}{*}{ Organizational Performance } & OP1 & 0.907 & 0.894 & 0.921 & 0.664 \\
\hline & OP3 & 0.813 & & & \\
\hline & OP4 & 0.73 & & & \\
\hline & OP5 & 0.888 & & & \\
\hline & OP6 & 0.621 & & & \\
\hline \multirow{3}{*}{ Service Design } & SD1 & 0.864 & 0.771 & 0.867 & 0.686 \\
\hline & SD2 & 0.808 & & & \\
\hline & SD3 & 0.811 & & & \\
\hline \multirow[t]{5}{*}{ Strategic Planning } & SP1 & 0.851 & 0.881 & 0.914 & 0.68 \\
\hline & SP2 & 0.859 & & & \\
\hline & SP3 & 0.702 & & & \\
\hline & SP5 & 0.885 & & & \\
\hline & SP6 & 0.814 & & & \\
\hline
\end{tabular}

\section{Discriminant Validity Analysis}

In order to ensure further construct validity of the outer model, the discriminant validity is important to be established. Hence, prior to hypotheses testing, discriminant validity was ensured. Discriminant validity refers to the level to which items can differentiate among different constructs in that it shows that the items of different constructs are not overlapping. Additionally, discriminant validity of measures share variance between each individual construct and hence it should be higher than the variance shared among specific constructs (Compeau, Higgins \& Huff, 1999). In this study, the discriminant validity of measures was established through Fornell and Larcker's (1981) method, where the square root of AVE for the entire 
constructs was replaced at the diagonal elements of the correlation matrix as demonstrated in Table 2.

Table 2: The Discriminant Validity Matrix

\begin{tabular}{cccccccccc}
\hline & B & CF & CI & CUO & IA & ML & OP & SD & SP \\
\hline B & $\mathbf{0 . 8 8 1}$ & & & & & & & & \\
CF & 0.554 & $\mathbf{0 . 8 3 8}$ & & & & & & & \\
CI & 0.769 & 0.568 & $\mathbf{0 . 8 3 5}$ & & & & & & \\
CUO & 0.622 & 0.650 & 0.690 & $\mathbf{0 . 8 8 6}$ & & & & & \\
IA & 0.727 & 0.672 & 0.793 & 0.804 & $\mathbf{0 . 8 0 5}$ & & & & \\
ML & 0.678 & 0.712 & 0.675 & 0.619 & 0.668 & $\mathbf{0 . 8 0 6}$ & & & \\
OP & 0.512 & 0.515 & 0.618 & 0.682 & 0.604 & 0.559 & $\mathbf{0 . 8 1 5}$ & & \\
SD & 0.729 & 0.592 & 0.777 & 0.696 & 0.844 & 0.642 & 0.544 & $\mathbf{0 . 8 2 8}$ & \\
SP & 0.676 & 0.805 & 0.760 & 0.643 & 0.766 & 0.818 & 0.509 & 0.673 & $\mathbf{0 . 8 2 5}$ \\
\hline
\end{tabular}

\section{Structural Model Evaluation}

After the confirmation of the goodness of the outer model, the next phase involves the testing of hypotheses relationships among the variables with the help of PLS Algorithm, Smart PLS. The path coefficients were produced and presented table 4

Table 4: Results of Hypothesis Testing

\begin{tabular}{lcccccl}
\hline Hyp.No & Hypothesis & $\begin{array}{c}\text { Path } \\
\text { Coefficient }\end{array}$ & $\begin{array}{c}\text { Standard } \\
\text { Error }\end{array}$ & T-Value & P-Value & Decision \\
\hline H1 & TQM $>$ > OP & $0.187^{* *}$ & 0.087 & 2.145 & 0.016 & Supported \\
H2 & ML -> OP & $0.162^{* *}$ & 0.098 & 1.642 & 0.050 & Supported \\
H3 & CF $>$ > OP & $0.169^{* *}$ & 0.085 & 1.987 & 0.024 & Supported \\
H4 & SP -> OP & -0.318 & 0.131 & 2.427 & 0.008 & Not Supported \\
H5 & SD -> OP & -0.095 & 0.100 & 0.952 & 0.171 & Not Supported \\
H6 & IA -> OP & 0.005 & 0.136 & 0.036 & 0.486 & Not Supported \\
H7 & CI -> OP & $0.290^{* * *}$ & 0.119 & 2.433 & 0.008 & Supported \\
H8 & B -> OP & -0.004 & 0.085 & 0.047 & 0.481 & Not Supported \\
\hline
\end{tabular}

Results and Discussion: Table 4 shows that hypothesis 1, 2, 3 and 7 were supported while hypothesis 4, 5, 6 and 8 were not supported. The discussion on these results is given in following section.

\section{Total Quality Management (TQM) and Organizational Performance}

The first objective of this study is to determine the effect of TQM on organizational performance therefore; the regression paths between the two constructs were examined. Table 4, , shows the relationship between TQM as a composite construct; and positive and significant organizational performance was discovered at 0.01 level of significance, which supports H1 $(\beta=0.187, \mathrm{t}=2.145, \mathrm{p}<0.05)$. This finding is in agreement with prior 
results from previous studies such as Wang et al., 2012; Zehir et al, 2012; Zhang, 2000. This result reflects the relevance of TQM practice among Pakistani bank branches in achieving their objectives and projected performance. Pakistani banks that succeeded in implementing TQM practices would obviously be capable of effectively handling customer complaints, achieving customer satisfaction, generating effective delivery system and increasing performance. Many studies in quality management literature have reported the positive and significant impact of TQM on organizational performance. According to Khamalah and Lingaraj (2007) and Kumar et al. (2009), the relevance of Total Quality Management as a management approach and a criteria for an organization to maintain it's market equity, keep grow and satisfy its customers. In addition, successful TQM implementation can assist Pakistani banks in enhancing their services prevent defects in daily their daily processes. The successful implementation of TQM practices for instance, reduces repetitive work, enhances services, and enhances satisfaction on both employees and customers end while facilitating the organization's planned objectives and generally improving the performance of the organization. In other words, successfully implemented TQM initiatives can lead to maintained and minimized error rates (Al-Mansour, 2007). In respect to the variation in the contribution level of every TQM critical factor (Montes \& Jover, 2004), this study went further while examining the significance of each factor with the hope that it might shed further light on each factor's quota to the banks for better use of resources.

Subsequently, emphasis should be placed on highly contributing TQM factors when implementing TQM; as prior literature showed mixed results in respect to the relationship between TQM dimensions and organizational performance (Rahman \& Bullock, 2005).

\section{Management Leadership (ML) and Organizational Performance}

This study's results show that management leadership positively and significantly affects organizational performance $(\beta=0.162, t=1.642, p<0.05)$ as presented in Table 4. This result supports $\mathrm{H} 2$ and is in coalition with prior studies with the same result such as, Abusa \& Gibson, 2013; Arawati, 2005; Flynn et al., 1995; Hendricks \& Singhal, 2001; Irefin, Abdul-Azeez, \& Hammed, 2011; Llorens Montes \& Verdu Jover, 2004; Powell, 1995; Talib et al., 2013; Yasin et al., 2004. They all emphasized on the significance of the leadership system with the undertone of clear vision and quality values for the stimulation of the whole organization and successful TQM implementation initiatives (Gupta et al., 2005). The leaders of the organization are in charge of relaying the vision quality policy and vision of the organization disseminate the goals of quality and enhance initiatives constantly (Rashid \& Aslam, 2012). They are also responsible for advocating and supporting team 
spirit/work among departments in order to achieve Total Quality Management objectives. This emphasizes on the importance of management leadership system supported by the entire employees 'capabilities in achieving needs of stakeholders and increasing satisfaction among customers via continuous improvement. And according to Ireland and Hitt (2005), organizational performance depends largely on the leadership styles adopted by managers; hence, the bank leaders need to adopt a strategy that provides training to both managers and leaders in order to produce transformational leaders. Within Pakistan context, this result shows the important role played by leadership in the implementation and development of TQM practice with the hopes of achieving the banks objectives - to enhance organizational performance. Just as recommended by Abusa (2013), this result shows that top management possess long-term quality plans and clear quality goals. Meanwhile, leaders and managers need to stress on high quality services provision to customers rather than stressing solely on the service cost.

\section{Customer Focus (CF) and Organizational Performance}

Data analysis results in Table 4 indicates that customer's focus has a positive and significant impact on organizational performance $(\beta=0.169$, $\mathrm{t}=1.987, \mathrm{p}<0.05)$ - supporting $\mathrm{H} 1 \mathrm{~b}$ while complementing prior findings such as Llorens-Montes \& Verdu-Jover 2004; and Yasin et al., 2004. Within this study's focus, customers who enjoy the bank performance can recommend the bank to relatives and friends. It is also an open secret that in today's market environment (in respect to banks) bank customers have become more critical of the quality and innovation of services offered by banks in such a way that they can easily move on to the next service provider if they are not satisfied. This is the typical behaviour of today's customer. This is why it is pertinent for banks to adopt strategies that are customer friendly and market oriented in order to enhance customer satisfaction levels (Al- Mansour, 2007). Pakistani banks should attempt to solidify customer trust and achieve satisfaction via high quality service provision (Abusa, 2013). Banks survival is at risk in the face of increasing competition with no customer focus strategies (Rana, 2004). In other words, customer focus helps prevent irrelevant processes and design services/activities that are underpinned by the needs and expectations of customers (Juran, 1988). Customers needs and expectations have to be measured and examined objectively by Pakistani banks in order to maintain customers loyalty and convert new leads while saving resources achieving the bank's objectives.

\section{Strategic Planning (SP) and Organizational Performance}

Strategic planning deals with the development and deployment of plans designed to enhance the relationship between the firm and its stakeholders 
(suppliers, business partners, customers) and to achieve long-term goals (Teh, Yong, Arumugam \& Ooi, 2009). The data analysis results in Table 4 of the previous chapter shows that strategic planning is inconsequential to organizational performance $(\beta=-0.318, \mathrm{t}=2.427, \mathrm{p}<0.01)$. It does not determine organizational performance, hence hypothesis $\mathrm{H} 1 \mathrm{c}$ is rejected. This result contradicts prior results from prior studies by Li et al. (2003), Sila and Ebrahimpour (2005) Sila and Ebrahimpour (2002), Talib et al. (2013) and Wu et al. (1997). This result shows that Pakinstani banks do not employ strategic planning practices. Thus, there is the need for managers in Pakistani banks to start paying attention to providing efficient service through strategic planning. Pakistani banks management need to be aware of strategic planning in order to practice them, in order to serve customers well and gain a edge over competitions in the dynamic marketplace.

\section{Information and Analysis (IA) and Organizational Performance}

An insignificant relationship was observed between information \& analysis construct and organizational performance $(\beta=0.005, t=0.036, p>0.1)$, thus, hypothesis H1f is rejected; which does not tally with results from prior studies by Ahire et al. (1996), Sila and Ebrahimpour (2005), Flynn et al. (1995), Kartha (2004), Ott and Van Dijk (2005), Powell (1995), Saraph et al. (1989), Sit, Ooi, Lin and Chong (2009). Relevant Total quality management literature agree that information and analysis system (IAS) play a significant role in the overall performance of banks by providing enhanced service quality, facilitating cost reduction, increase in productivity, reduced risk and uncertainty in the decision making process, and it maximizes workforce (Bilich and Neto, 2000). However, this study shows a negative impact of IAS on organizational performance in Pakistani banks. These discrepancies can be shelved on the incompetence of Pakistani banks communication and information system. Backing up this result, Shibani et al., (2012) also found an insignificant relationship between the two constructs.

\section{Continuous Improvement (CI) and Organizational Performance}

Talib et al. (2013) stated continuous improvement among the critical factors facilitating ongoing improvement of organizational performance. In reference to the results presented in Table 4, continuous improvement significantly determines organizational performance $(\beta=0.290, t=2.433$, $\mathrm{p}<0.01)$. This result complements those observed by prior studies such as Yusuf et al. (2007), Benavent et al. (2005), Christos et al. (2010), Gatchalian (1997), Lakshman (2006); Powell (1995) and Talib et al. (2013). This result indicates that Pakistani banks pay attention to continuous improvement practices and ensure their effective implementation. This study complements Abusa (2013) that observed that continuous improvement practices 
significantly affects organizational performance in Pakistani Industrial Sector.

\section{Benchmarking (B) and Organizational Performance}

Benchmarking assists in conducting a comparison of the organizational performance based on internal or external aspects of the organization (Talib et al., 2013). This study observed that benchmarking while significantly impacting on organizational performance, also negatively impact it $(\beta=-0.004$, $\mathrm{t}=0.047, \mathrm{p}<0.01$ ) which is contrary to those of prior studies (Talib et al. ,2013; Ahire et al., 1996; Arawati, 2005; Powell, 1995; Christos et al., 2010; Terziovski \& Samson, 1999) that discovered the same positive significant impact on organizational performance. While other studies like Dow et al. (1999) showed that benchmarking does not contribute to quality results. This result can however be explained in argument that some soft TQM factors may contribute more to the improvement of organizational performance compared to some hard TQM factors like benchmarking (Samson \& Terziovski, 1999). Powell (1995) also observed an inconsequential effect of benchmarking on organizational performance and came to the conclusion that the success of Total Quality Management implementation may not be dependent on benchmarking. Shibani et al., (2012) reported that benchmarking is at the top of barriers for TQM implementation in companies, within the Pakistan context. While it is important for Pakistani banks to view benchmarking as a strategy for achieving top competitive advantage, they should equally call for more research to be carried out in order to determine the best practices in international and local banks.

\section{Contributions of the Study}

This study provides many insights to issues related to the organizational performance of Pakistani banks and considering it is one of the very few studies to have been conducted in the Asia world to examine the combined effect of TQM on organizational performance, expanding the boundary of existing knowledge, it is a valuable contribution.

\section{Contributions to the Literature}

This study aim to contribute to the knowledge of the relationship between Total Quality Management and organizational performance. With precedents on findings from prior studies, this study's framework was developed in order to examine the proposed hypotheses. Chapter one provides the significance of the study while the contributions of the study are provided and discussed in this section. First, this study pays great service to literature by shedding light on the importance of Total Quality Management in the service sector in a section lacking one - Pakistani banks. 
Where prior studies relied on traditional instruments like factor analysis and Cronbach alpha coefficient for such validation - efficient but not sufficient for this study's present analysis - this study carried out well-researched analysis on the validation of instrument in addition to testing hypotheses and the model. Partial Least Squares Structural Equation Modeling (PLS-SEM) method was used for validating the measurement model and testing the proposed hypotheses in this study, making it one of the few studies to have used such method for adequate fit of the measurement model in hypotheses testing.

\section{Practical Contributions}

The findings of the study provide a clear insight into TQM and its role in improving organizational performance as a whole; which benefits practitioners, academics, policy makers and managers; in other words, it is a beneficial contribution to TQM related literature.

\section{Practical contributions of these findings are:}

In movement literature, Total Quality Management has been observed to facilitate competitive advantages of the organization, thus, improving performance. Managers and decision makers of Pakistani banks are enlightened on the significance of Total Quality Management implementation. Like every other banks, Pakistani banks are constantly in search of strategies and systems that will help them achieve the best result; thus, they are made aware that it is essential to implement TQM to steer clear of any issues that might arise from inadequate strategies.

\section{Limitations of the Study}

Although this study researcher experienced necessary effort in ensuring that it achieves the basic objectives, offering practical and theoretical contributions to past studies, it has its own limitations.

The first study limitation arose from the adopted cross-sectional research design used in examining the hypothesized relationships - the design focuses on a single point of time while the psychological human aspects are constantly changing. This research design limited the light shed on the relationships between TQM and organizational performance. Employing longitudinal design may have given the researcher a different conclusion.

The second limitation is in respect to the quantitative research method, where respondents were asked to describe their perceptions according to the items in the survey questionnaire and gauge them through the Likert scale. These answers by respondents may have been influenced by their biased perception of the subject matter (Macinati, 2000). Whereas a mixed research designs with both quantitative and qualitative research designs may have achieved a better result. 
The third limitation is due to lack of adequate studies dedicated to the phenomenon in focus within the context of Pakistan. Thereby limiting the researcher's ability to compare and contrast with other studies of the same status.

\section{Suggestions for Future Research}

This study is porous; which leaves loopholes worthy of pursuit by future researchers. For one, the cross-sectional data collection approach used in this study does not shed enough light on the relationship changes between TQM and organizational performance. However, this research may be extended through a longitudinal method owing to the complexity involved in examining strategies like TQM and organizational performance. This allows the complexity of the relationship to be explained over a period of time and development of variables may be observed during this period to shed clearer and better light on the relationship changes between TQM and Organizational performance.

Secondly, this study's results are collated based on data from different Pakistan bank branches because they have more knowledge of Effects on organizational performance, however, future studies can be broadened to include customers, as they are at the receiving end of the service, and the employees. Thirdly, the research method used in this study requested the researcher observe the nature of relationships and their impacts within one point at a time. Whereas a case study approach would allow the researcher to minutely examine the relationships for a complete examination of the impact of TQM on organizational performance. This model can be used when studying other sectors of the market, especially in a country with rigid and unique culture in addition to the scope of the findings.

Conclusively, this results can be enhanced by future research on TQM and organizational performance, focusing on individual constructs.

\section{References:}

1. Abusa, Fuzi M, \& Gibson, Peter. (2013). TQM implementation in developing countries: a case study of the Libyan Industrial Sector. Benchmarking: An International Journal, 20(5), 693-711.

2. Abusa, Fuzi. (2011). TQM implementation and its impact on organisational performance in developing countries: a case study on Libya.

3. Agus, Arawati. (2005). The structural linkages between TQM, product quality performance, and business performance: preliminary empirical study in electronics companies. Singapore Management Review, 27(1), 87-105.

4. Agus, Arawati. (2005). The structural linkages between TQM, product 
quality performance, and business performance: preliminary empirical study in electronics companies. Singapore Management Review, 27(1), 87-105.

5. Ahire, Sanjay L, Golhar, Damodar Y, \& Waller, Matthew A. (1996). Development and validation of TQM implementation constructs. Decision sciences, 27(1), 23-56.

6. Al-Marri, Khalid, Ahmed, Abdel Moneim M Baheeg, \& Zairi, Mohamed. (2007). Excellence in service: an empirical study of the UAE banking sector. International Journal of Quality \& Reliability Management, 24(2), 164-176.

7. Al-Marri, Khalid, Ahmed, Abdel Moneim M Baheeg, \& Zairi, Mohamed. (2007). Excellence in service: an empirical study of the UAE banking sector. International Journal of Quality \& Reliability Management, 24(2), 164-176.

8. Benavent, F Balbaster, Ros, S Cruz, \& Moreno-Luzon, M. (2005). A model of quality management self-assessment: an exploratory research. International Journal of Quality \& Reliability Management, 22(5), 432451.

9. Benavent, F Balbaster, Ros, S Cruz, \& Moreno-Luzon, M. (2005). A model of quality management self-assessment: an exploratory research. International Journal of Quality \& Reliability Management, 22(5), 432451.

10. Bhuian, Shahid N, Menguc, Bulent, \& Bell, Simon J. (2005). Just entrepreneurial enough: the moderating effect of entrepreneurship on the relationship between market orientation and performance. Journal of business research, 58(1), 9-17.

11. Burli, S. B., Kotturshettar, B. B. \& Dalmia, R. V. (2012). Multiple Performance Measures: Six TQM Practices. SCMS Journal of Indian Management, 69-79.

12. Combs, James G, Crook, T Russell, \& Shook, Christopher L. (2005). The dimensionality of organizational performance and its implications for strategic management research. Research methodology in strategy and management, 2, 259-286.

13. Compeau, Deborah, Higgins, Christopher A, \& Huff, Sid. (1999). Social cognitive theory and individual reactions to computing technology: A longitudinal study. MIS quarterly, 145-158.

14. Das, Abhiman, Ray, Subhash C, \& Nag, Ashok. (2009). Labor-use efficiency in Indian banking: a branch-level analysis. Omega, 37(2), 411-425.

15. Dhafer Al-Qahtani, Norah \& Sa 'ad Alshehri, Sabah \& Abdaziz, Azrilah. (2015). The impact of Total Quality Management on organizational performance. European Journal of Business and 
Management. 7. 2015.

16. Douglas, T. J., \& Judge Jr, W. Q. (2001). Total quality management implementation and competitive advantage: the role of structural control and exploration. Academy of Management Journal, 44(1), 158169.

17. Dubey, R. (2015). An insight on soft TQM practices and their impact on cement manufacturing firm's performance: does size of the cement manufacturing firm matter? Business Process Management Journal, 21(1), 2-24.

18. Dubey, R., Singh, T., \& Ali, S. S. (2015). The mediating effect of human resource on successful total quality management implementation: An empirical study on SMEs in manufacturing sectors. Benchmarking: An International Journal, 22(7), 1463-1480.

19. Escrig-Tena, Ana Belén. (2004). TQM as a competitive factor: a theoretical and empirical analysis. International Journal of Quality \& Reliability Management, 21(6), 612-637.

20. Farrukh, M., Chong, W. Y., Mansori, S., \& Ravan Ramzani, S. (2017). Intrapreneurial behaviour: the role of organizational commitment. World Journal of Entrepreneurship, Management and Sustainable Development, 13(3), 243-256. https://doi.org/10.1108/WJEMSD-032017-0016

21. Farrukh, M., Khan, A. A., Khan, A. A., Shahid Khan, M., Shahid Khan, M., Ravan Ramzani, S., ... Soladoye, B. S. A. (2017). Entrepreneurial intentions: the role of family factors, personality traits and selfefficacy. World Journal of Entrepreneurship, Management and Sustainable Development, 13(4), 303-317.

22. Farrukh, M., Wei Ying, C., \& Abdallah Ahmed, N. O. (2016). Organizational commitment: Does religiosity matter? Cogent Business \& Management, 3(1), 1-10. https://doi.org/10.1080/23311975.2016.1239300

23. Farrukh, M., Ying, C. W., \& Mansori, S. (2017). Organizational commitment: an empirical analysis of personality traits. Journal of Work-Applied Management, 9(1), 18-34.

24. Farrukh, M., Ying, C., \& Mansori, S. (2016). Intrapreneurial behavior : an empirical investigation of personality traits Research issue. Management \& Marketing. Challenges for the Knowledge Society, 11(4), 597-609. https://doi.org/10.1515/mmcks-20160018.Introduction

25. Fase, Martin MG, \& Abma, RCN. (2003). Financial environment and economic growth in selected Asian countries. Journal of Asian Economics, 14(1), 11-21.

26. Finkelstein, S., \& Hambrick, D. C. (1996). Strategic Leadership: Top 
executives and their effects on organizations. New York: West.

27. Flynn, Barbara B, Sakakibara, Sadao, \& Schroeder, Roger G. (1995). Relationship between JIT and TQM: practices and performance. Academy of management Journal, 38(5), 1325-1360

28. Fotopoulos, Christos V, \& Psomas, Evangelos L. (2010). The structural relationships between TQM factors and organizational performance. The TQM Journal, 22(5), 539-552.

29. Hooley, Graham, Fahy, John, Greenley, Gordon, Beracs, József, Fonfara, Krzysztof, \& Snoj, Boris. (2003). Market orientation in the service sector of the transition economies of central Europe. European Journal of Marketing, 37(1/2), 86-106.

30. Chelliah, S., Sulaiman, M., \& Yusoff, Y. M. (2010). Internationalization and performance: Small and medium enterprises (SMEs) in Malaysia. International Journal of Business and Management, 5(6), p27.

31. Chenhall, Robert H. (2005). Integrative strategic performance measurement systems, strategic alignment of manufacturing, learning and strategic outcomes: an exploratory study. Accounting, Organizations and Society, 30(5), 395-422.

32. Choi, David, \& Valikangas, Liisa. (2001). Six Sigma and TQM cannot create sustainable value unless coupled with a more innovative strategy. Strategy and Business, 23, 15-16.

33. Choi, Thomas Y, \& Eboch, Karen. (1998). The TQM paradox: relations among TQM practices, plant performance, and customer satisfaction. Journal of Operations Management, 17(1), 59-75.

34. Irani, Z, Beskese, A, \& Love, PED. (2004). Total quality management and corporate culture: constructs of organisational excellence. Technovation, 24(8), 643-650.

35. Jing, Fenwick Feng, \& Avery, Gayle C. (2011). Missing links in understanding the relationship between leadership and organizational performance. International Business \& Economics Research Journal (IBER), 7(5).

36. Kartha, CP. (2004). A comparison of ISO 9000: 2000 quality system standards, QS9000, ISO/TS 16949 and Baldrige criteria. The TQM Magazine, 16(5), 331-340.

37. Kaynak, Erdener, \& Kucukemiroglu, Orsay. (1992). Bank and product selection: Hong Kong. International Journal of Bank Marketing, 10(1), 3-16.

38. Kaynak, Erdener, \& Kucukemiroglu, Orsay. (1992). Bank and product selection: Hong Kong. International Journal of Bank Marketing, 10(1), 3-16.

39. Khamalah, Joseph N, \& Lingaraj, Bangalore P. (2007). TQM in the 
service sector: a survey of small businesses. Total quality management, 18(9), 973-982.

40. Kober, R., Subraamanniam, T., \& Watson, J. (2012). The impact of total quality management adoption on small and medium enterprises' financial performance. Accounting \& Finance, 52(2), 421-438.

41. Kumar, Vinod, Choisne, Franck, de Grosbois, Danuta, \& Kumar, Uma. (2009). Impact of TQM on company's performance. International journal of quality \& reliability management, 26(1), 23-37.

42. Lakhe, RR, \& Mohanty, RP. (1995). Understanding TQM in service systems. International Journal of Quality \& Reliability Management, 12(9), 139-153.

43. Lakshman, C. (2006). A theory of leadership for quality: Lessons from TQM for leadership theory 1. Total Quality Management \& Business Excellence, 17(1), 41-60.

44. Landau, Dana, Drori, Israel, \& Porras, Jerry. (2006). Vision Change in a Governmental R\&D Organization The Pioneering Legacy as an Enduring Element. The Journal of Applied Behavioral Science, 42(2), 145-171.

45. Matzler, Kurt, Hinterhuber, Hans H, Daxer, Christian, \& Huber, Maximilian. (2005). The relationship between customer satisfaction and shareholder value. Total Quality Management \& Business Excellence, 16(5), 671-680.

46. Mehra, S., Hoffman, J. M. , \& Sirias, D. (2001) .TQM as a management strategy for the next millennium. International Journal of Operations \& Production Management, 21(5/6), 855-876

47. Montes, Fco Javier Llorens, Jover, Antonio Verdu, \& Fernandez, Luis Miguel Molina. (2003). Factors affecting the relationship between total quality management and organizational performance. International Journal of Quality \& Reliability Management, 20(2), 189-209.

48. Nair, Anand. (2006). Meta-analysis of the relationship between quality management practices and firm performance - implications for quality management theory development. Journal of Operations Management, 24(6), 948-975.

49. Riaz, Q., Farrukh, M., Rehman, S. U., \& Ishaque, A. (2016). Religion and entrepreneurial intentions: an empirical investigation. International Journal of Advanced and Applied Sciences, 3(9), 31-36.

50. Richard Jimoh, Luqman Oyewobi, Rasheed Isa \& Ibrahim Waziri (2018) Total quality management practices and organizational performance: the mediating roles of strategies for continuous improvement,International Journal of Construction Management, DOI: 10.1080/15623599.2017.1411456

51. Rula Ali Al-Damen(2017)The impact of Total Quality Management on 
organizational performance. Case of Jordan Oil Petroleum Company, International Journal of Business and Social Science. Vol. 8, No. 1.

52. Sahoo, S., \& Yadav, S. (2017). Entrepreneurial orientation of SMEs, total quality management and firm performance. Journal of Manufacturing Technology Management, 28(7), 892-912.

53. Samson, D., \& Terziovski, M. (1999). The relationship between total quality management practices and operational performance. Journal of Operations Management, 17(4), 393-409.

54. Samson, D., \& Terziovski, M. (1999a). The link between TQM practices and organizational performance. International Journal of Quality \& Reliability Management, 16(3), 226-262.

55. Samson, D., \& Terziovski, M. (1999b). The relationship between total quality management practices and operational performance. Journal of Operations Management, 17(3), 393-409

56. Saraph, Jayant V, Benson, P George, \& Schroeder, Roger G. (1989). An instrument for measuring the critical factors of quality management. Decision sciences, 20(4), 810-829.

57. Shahzad, I. A., Farrukh, M., Kanwal, N., \& Sakib, A. (2018). Decisionmaking participation eulogizes probability of behavioral output; job satisfaction, and employee performance (evidence from professionals having low and high levels of perceived organizational support). World Journal of Entrepreneurship, Management and Sustainable Development.

58. Shibani, Abdussalam, Saidani, Messaoud, \& Gherbal, Nawal. (2012). An evaluation of obstacles preventing implementation of TQM in Libyan organisations. Bus. Manage. Res. J, 1(3), 84-91.

59. Sila, Ismail, \& Ebrahimpour, Maling. (2002). An investigation of the total quality management survey based research published between 1989 and 2000: a literature review. International Journal of Quality \& Reliability Management, 19(7), 902-970.

60. Sila, Ismail, \& Ebrahimpour, Maling. (2005). Critical linkages among TQM factors and business results. International journal of operations \& production management, 25(11), 1123-1155

61. Simpson, M., Padmore, J., \& Newman, N. (2012). Towards a new model of success and performance in SMEs. International Journal of Entrepreneurial Behavior \& Research, 18(3), 264-285.

62. Srinidhi, Bin. (1998). Strategic quality management. International Journal of Quality Science, 3(1), 38-70.

63. Thai, V., \& Jie, F. (2018). The impact of total quality management and supply chain integration on firm performance of container shipping companies in Singapore. Asia Pacific Journal of Marketing and Logistics, (just-accepted), 0. 
64. Thiagarajan, T., \& Zairi, M. (1997a). A review of total quality management in practice: Understanding the fundamentals through examples of best practice application- Part I. The TQM Magazine, 9 (4), 270-286.

65. Yasin, Mahmoud M, Alavi, Jafar, Kunt, Murat, \& Zimmerer, Thomas W. (2004). TQM practices in service organizations: an exploratory study into the implementation, outcome and effectiveness. Managing Service Quality, 14(5), 377-389. 